\title{
Evaluation of Hygiene Practices and oral Health Condition of Patients with Visual Impairment
}

\section{Avaliação das Práticas de Higiene e Condição de Saúde Bucal de Pacientes com Deficiência Visual}

\author{
Clea Adas Saliba Garbin; Mariana Martins Ortega*a; Artênio José Ísper Garbina; Tânia Adas Saliba ${ }^{\mathrm{a}}$
}

\author{
âniversidade Estadual Paulista Júlio de Mesquita Filho, Programa de Pós-Graduação em Odontologia Preventiva e Social. SP, Brasil \\ *E-mail: mmartins.ortega@gmail.com \\ Recebido em: 25/04/2019; Aprovado em: 13/08/2019
}

\begin{abstract}
The objective was evaluate the oral hygiene practices, the periodontal condition and the edentulism of the person with visual impairment. This is a cross-sectional quantitative study in which the study population was a visually impaired person from an Institute for the blind of a medium-sized municipality. The variables studied were: gender, level and type of visual impairment, frequency of oral brushing and methods used for oral hygiene, periodontal situation and use and need of dental prosthesis. The participants of the study ( $\mathrm{n}=47), 70.2 \%$ were males, with a mean age of $47.2 \pm 14.1$ years. Regarding toothbrushing, $66.0 \%$ stated that they brush their teeth more than twice a day, but dental floss is never used by $51.1 \%$ of the interviewees. When comparing the use of dental prosthesis with flossing, a statistically significant difference was found $(p=0.043)$. The same is observed in relation to the CPI score, in which a statistically significant value $(p=0.000)$ was found. The correlation coefficient was statistically significant, of moderate strength $(r=0.681)$ at the intersection of the CPI Score with the Prosthesis Use Score. Although people with visual impairments frequently perform oral hygiene practices, dental hygiene is often out of date due to the lack of flossing. This lag is due to the lack of public policies aimed at this population. This fact reflects negatively on the oral health conditions of these patients, who presented teeth with periodontal problems and a high prevalence of edentulism.
\end{abstract}

Keywords: Vision Disorders. Oral Hygiene. Periodontal Index.

\section{Resumo}

O objetivo foi avaliar as práticas de higiene bucal, a condição periodontal e o edentulismo das pessoas com deficiência visual. Trata-se de um estudo quantitativo, de caráter transversal, no qual a população de estudo foram pessoas portadoras de deficiência visual, de um Instituto para cegos de um munícipio de médio porte. As variáveis pesquisadas foram: gênero, nível e tipo de deficiência visual, frequência de escovação bucal e métodos utilizados de higiene bucal, situação periodontal e uso e necessidade de prótese dentária. Dos participantes do estudo (n=47), $70,2 \%$ são do sexo masculino, com uma média de idade de 47,2 $\pm 14,1$ anos. Em relação à escovação 66,0\% afirmaram que escovam os dentes mais de duas vezes ao dia, porém o fio dental nunca é utilizado por $51,1 \%$ dos entrevistados. Quando comparados o uso de prótese dentária com o uso do fio dental, foi encontrada diferença estatisticamente ( $p=0,043)$. O mesmo é observado em relação ao escore CPI, no qual foi encontrado valor estatisticamente significante $(p=0,000)$. O coeficiente de correlação foi estatisticamente significativo, de força moderada $(r=0,681)$ no cruzamento do Score CPI com o Score Uso de Prótese. Apesar das pessoas com deficiência visual realizarem as práticas de higiene bucal com frequencia, esta se encontra defasada devido à falta do uso do fio dental. Essa defasagem se da devido à falta de politicas públicas voltadas para essa população. Fato este que reflete negativamente nas condições de saúde bucal desses pacientes, que apresentaram dentes com problemas periodontais e uma alta prevalência de edentulismo.

Palavras-chave: Transtornos da Visão. Higiene Bucal. Índice Periodontal.

\section{Introduction}

According to the National Health Survey (Pesquisa Nacional de Saúde - PNS), an estimate of $6.2 \%$ of the Brazilian population has at least one of these four disabilities: intellectual, physical, hearing and visual. Visual disability is the most representative in the population, with a proportion of $3 . \%^{1}$.

Visual impairment is characterized by a change in one's functional capabilities due to factors such as significant impairment of acuity and significant reduction of the visual field and contrast sensitivity ${ }^{2}$. Visually impaired people may find challenges in many areas of their lives, from physical barriers, adaptations to the educational process and insertion in the society, to daily routine activities, such as getting dressed, eating and carrying out personal hygiene ${ }^{3}$. In this context, maintaining adequate oral hygiene may become a major problem for these individuals due to their poor motor skills when carrying out satisfactory oral hygiene.

Thus,oral health education programs for people with visual impairment are important, but they are not common in the public health system, and these are usually carried out for people with disabilities as a whole, not specific for each type $^{4}$. Some Dental Specialty Centers (DSCs) are trained to perform care for these people, the state of São Paulo has only 77 specialized centers 5 .

Some studies have developed effective oral health 
education programs for people with visual impairment $t^{6,7}$. These programs consist of teaching oral health techniques in three ways, using Braille booklets, verbal forms with audio stories, and tactile demonstrations on plastic models ${ }^{8}$. Despite this, most public dental surgeons are often unable to develop these programs, causing a lag in the process of oral health education for people with visual impairment ${ }^{9}$

For example, they have difficulties flossing, which may lead to the accumulation of dental plaque and result in a gingival inflammatory process, which, in turn, may lead to dental calculus and evolve into a periodontal issue and potential tooth $\operatorname{loss}{ }^{10}$.

Periodontal diseases can be described as inflammatory processes caused by infections induced by microorganisms of the dental biofilm (bacterial plaque), leading to reactions in the periodontal tissues and damaging the connective tissue and the alveolar bone. Therefore, to prevent periodontal diseases, it is necessary to correctly remove the bacterial plaque through tooth brushing and flossing ${ }^{11}$.

The consequence of advanced periodontal issues may be the tooth loss, which limits functions directly associated with the maintenance of quality of life. The impacts caused by the lack of teeth are the reduction of chewing and phonation capabilities, as well as nutritional, aesthetic and psychological damages, such as the reduction of self-esteem and social integration $^{12}$.

In people with visual impairment, self-esteem reductions may be more evident, as they tend not to be good with themselves, which leads to a non-acceptance of their situation, thus depreciating their self-esteem. This is influenced by conditioning factors of good or malaise and in this way the condition of oral health can interfere directly in the selfesteem of those individuals ${ }^{13,14}$.

Considering this scenario, the objective of this study was to assess oral hygiene practices, periodontal condition and edentulism of visually impaired people.

\section{Material and Methods}

The study was approved by the Research Ethics Committee of FOA-UNESP through the Brazil Platform (CAAE: 76484317.8.0000.5420). It is also important to highlight that the research was guided by Resolution 466/2012 of the National Health Council (CNS) of the Ministry of Health Brazil.

This is a cross-sectional, quantitative study covering people with visual impairment (complete blindness and low vision) from an institute for blind people in a medium-sized city.

A letter was sent to the institute explaining the objectives and benefits of the research in order to obtain their approval.

All those who frequently visit the institute were invited to participate in the research $(n=150)$, but only those who met the inclusion and exclusion criteria participated in the study.
The inclusion criteria were being capable of answering the questionnaire, signing the term of free, informed consent and being present in the days of the visits. The exclusion criteria were individuals with intellectual impairment or who did not understand the questions, the subjects who were not present on the days of the visits, as well as the children because they do not evaluate periodontal condition for this type of population. Resulting in a total of 42 research participants.

A semi-structured questionnaire with open and multiplechoice questions was developed by the researchers based on other studies about the theme. The variables studied were gender, level and type of visual impairment, frequency of teeth brushing and methods used for oral hygiene.

As for the collection, weekly visits were carried out, so that the instruments were applied individually, by a calibrated examiner, who recorded all the participants' responses. This procedure was adopted due to the condition of the population studied and the impossibility of transcribing the questionnaire into braille, as not all participants were able to read it.

The free and informed consent term was read aloud by the researcher and, upon agreeing to the research, the interviewee made the signature through fingerprinting.

After data collection, the oral hygiene guidelines were individually performed, in an adapted manner.

To evaluate participants' periodontal condition and edentulism, a clinical examination was carried out by a skilled researcher, under natural light, with a mirror and periodontal probe, following the recommendations of the World Health Organization $(\mathrm{WHO})^{15}$. To evaluate the periodontal condition, the modified Community Periodontal Index (CPI) was used and gingival bleeding, dental calculus and periodontal pockets were found in index teeth 17/16, 11, 26/27, 36/37, 31, 46/47, the worst condition was written down. To evaluate edentulism, the usage criteria and the need for dental prosthesis as recommended by $\mathrm{WHO}^{15}$ were used, evaluating whether each participant wore prosthesis and its type, doing the same regarding the need.

The investigator was calibrated by means of an intraexaminer test, with a kappa index of 0.89. It is worth remembering that the Kappa coefficient ranges from " 0 " to "1", where " 0 " means absolute disagreement between the examiners and " 1 ", the absolute agreement between them. It is also noted that the WHO standards for this clinical examination were followed. In addition, the data were annotated according to WHO codes and then tabulated.

The data analysis was descriptive and analytical, in which the categorical variables were expressed by their absolute and relative frequencies. For the variables CPI, use and need of prosthesis, scores were assigned, in which the highest score corresponded to the worst condition. The data normality was verified by the Kolmogorov-Smirnov test. The non-parametric Mann-Whitney and Kruskal-Wallis tests and the Spearman correlation test were used, all with the level of significance 
adopted of $5 \%(\mathrm{p}<0.05)$. The data were tabulated by Epi Info 7.2, and the analysis was performed by BioEstat 5.3.

\section{Results and Discussion}

Out of the analyzed population $(n=47), 70.2 \%$ were male, and the age average was $47.2 \pm 14.1$ years old. Regarding the level of visual impairment, 59.6\% were completely blind and $40.4 \%$ had low vision. $78.7 \%$ of the participants acquired their impairment over the course of their lives. Regarding teeth brushing, $66.0 \%$ stated they brushed their teeth more than twice a day, $25.5 \%$ up twice , and $8.5 \%$ only once a day. When asked about how they learned their teeth brushing technique, $63.8 \%$ answered they learned it with their father or mother, $14.9 \%$ at school, $8.5 \%$ at the dentist and $12.8 \%$ stated that no one had ever taught them how to brush their teeth.

Regarding the methods used for carrying out oral hygiene, $51.5 \%$ of interviewees never used dental floss and $61.7 \%$ never used mouthwash (Table 1).

Table 1 - Frequency of use and methods used for carrying out oral hygiene

\begin{tabular}{|l|c|c|c|c|c|c|}
\hline \multirow{3}{*}{ Variables } & \multicolumn{6}{|c|}{ Methods used in oral hygiene } \\
\cline { 2 - 7 } & $\begin{array}{c}\text { Toothbrush } \\
\text { and toothpaste }\end{array}$ & \multicolumn{2}{|c|}{ Floss } & \multicolumn{2}{|c|}{ Mouthwash } \\
\cline { 2 - 7 } & $\mathbf{n}$ & $\%$ & $\mathbf{n}$ & $\%$ & $\mathbf{n}$ & $\%$ \\
\hline \multicolumn{7}{|c|}{ Frequency of use } \\
\hline Never & 0 & 0.00 & 24 & 51.1 & 29 & 61.7 \\
\hline Sometimes & 1 & 2.1 & 12 & 25.5 & 12 & 25.5 \\
\hline Always & 46 & 97.9 & 11 & 23.4 & 6 & 12.8 \\
\hline Total & 47 & 100.00 & 47 & 100.00 & 47 & 100.00 \\
\hline
\end{tabular}

Source: The authors.

Regarding periodontal conditions, 282 index teeth were analyzed, out of which $42.2 \%$ were healthy, $1.1 \%$ showed bleeding, $15.3 \%$ had dental calculus, $1.1 \%$ had shallow pockets and $33.7 \%$ were excluded, because they were not present in the mouth..

Regarding the use of dental prosthesis on the upper arch, out of the $29.8 \%$ who wore some kind of prosthesis, $17 \%$ wore total prosthesis (TP). Regarding the use of dental prosthesis on the lower arch, out of the $23.4 \%$ who wore some kind of prosthesis, $12.8 \%$ wore total prosthesis (Table 2).

Table 2 - Absolute and percentage distribution of the individuals regarding the use of dental prosthesis

\begin{tabular}{|l|c|c|c|c|}
\hline \multirow{2}{*}{\multicolumn{1}{|c|}{ Variables }} & \multicolumn{4}{c|}{ Arch } \\
\cline { 2 - 6 } & \multicolumn{2}{|c|}{ Upper } & \multicolumn{2}{c|}{ Lower } \\
\cline { 2 - 6 } & $\mathbf{n}$ & $\mathbf{\%}$ & $\mathbf{n}$ & $\mathbf{\%}$ \\
\hline Prosthesis Use & 30 & 63.8 & 33 & 70.2 \\
\hline Does not wear & 2 & 4.3 & 1 & 2.1 \\
\hline Wears a FB & 4 & 8.5 & 3 & 6.4 \\
\hline Wears a RPP & 0 & 0.0 & 1 & 2.1 \\
\hline Wears more than one FB or RPP & 8 & 17.0 & 6 & 12.8 \\
\hline Wears a Total Prosthesis & 3 & 6.4 & 3 & 6.4 \\
\hline No Information & 47 & 100.0 & 47 & 100.0 \\
\hline Total & \multicolumn{5}{|c}{} \\
*FB - Fixed Bridge; RPP - Removable Partial Prosthesis \\
Source: The authors.
\end{tabular}

Regarding the need for dental prosthesis, $42.6 \%$ did not need any type of dental prosthesis. Out of the $55.7 \%$ that needed some type of prosthesis: $27.7 \%$ needed a partial prosthesis on one jaw, $21.3 \%$ needed a partial prosthesis on both jaws, $2.1 \%$ needed a total prosthesis on one jaw, 2.1\% needed a total prosthesis on both jaws, and $4.3 \%$ did not have information regarding the need for prosthesis.

When comparing the use of dental prosthesis with flossing, a statistically significant difference was found $(p=0.043)$, that is, those who floss more frequently use less dental prosthesis. The same is observed in relation to the CPI score, in which a statistically significant value $(\mathrm{p}=0.000)$ was found, thus it was observed that those who use the dental floss more frequently have a lower CPI score (Table 3).

Table 3 - Comparative analysis of the variables in relation to prosthesis use score and CPI score

\begin{tabular}{|c|c|c|c|c|c|c|c|}
\hline \multirow{2}{*}{ Variables } & \multicolumn{2}{|c|}{$\begin{array}{c}\text { Frequency you brush your } \\
\text { teeth }\end{array}$} & \multicolumn{3}{|c|}{ Flossing } & \multicolumn{2}{|c|}{ Level of disability } \\
\hline & $\begin{array}{c}\text { Once or } \\
\text { twice a day }\end{array}$ & $\begin{array}{l}\text { More than } \\
\text { twice a day }\end{array}$ & Never & Sometimes & Ever & $\begin{array}{c}\text { Total } \\
\text { Blindness }\end{array}$ & Low Vision \\
\hline \multicolumn{8}{|c|}{ Use of prosthesis score } \\
\hline $\mathrm{n}$ & 16 & 28 & 22 & 11 & 11 & 26 & 18 \\
\hline Average & 2.1 & 2.2 & $3.6_{B}$ & $0.4_{A}$ & $1.0_{A B}$ & 2.6 & 1.4 \\
\hline Standard deviation & 3.8 & 3.5 & 4.3 & 0.9 & 2.2 & 3.7 & 3.3 \\
\hline p-value & \multicolumn{2}{|c|}{$0,806^{*}$} & \multicolumn{3}{|c|}{$0.043 * *$} & \multicolumn{2}{|c|}{$0.193 *$} \\
\hline \multicolumn{8}{|c|}{ Score CPI } \\
\hline $\mathrm{n}$ & 16 & 28 & 23 & 10 & 11 & 27 & 17 \\
\hline Average & 13.7 & 12.6 & $19.5_{B}$ & $2.5_{\mathrm{A}}$ & $9.0_{\mathrm{A}}$ & 15.2 & 9.5 \\
\hline Standard deviation & 11.8 & 11.8 & 11.4 & 3.6 & 7.9 & 12.3 & 9.9 \\
\hline p-value & \multicolumn{2}{|c|}{$0.556^{*}$} & \multicolumn{3}{|c|}{$0.000 * *$} & \multicolumn{2}{|c|}{$0.239^{*}$} \\
\hline
\end{tabular}

* Mann-Whitney test ** Kruskal-Wallis test

Source: The authors.

The correlation coefficient was statistically significant at the intersection of the CPI Score with the Prosthesis Use
Score. This coefficient has moderate strength $(r=0.681)$ and is positive, that is, as the CPI Score increases, the Score 
Usage of Prosthesis also increases (Table 4). In relation to Age and CPI Score, there was a statistically significant positive correlation $(\mathrm{p}=0.000)$, moderate strength $(\mathrm{r}=0.566)$, that is, the CPI Score increased with age. The same was observed in relation to Age and Score of Use of prosthesis, in which the correlation coefficient has moderate strength $(r=0.495)$ and is positive, that is, the score of use of prosthesis increases with age (Table 4 ).

Table 4 - Correlation analysis among the variables

\begin{tabular}{|l|c|c|}
\hline \multirow{2}{*}{\multicolumn{1}{|c|}{ Crossings }} & \multicolumn{2}{c|}{ Correlation } \\
\cline { 2 - 3 } & Coefficient & p-value \\
\hline Score CPI x Score Use of Prosthesis & $0.681^{*}$ & 0.000 \\
\hline Score CPI x Score Prosthesis Needed & 0.100 & 0.524 \\
\hline Age x Score CPI & $0.566^{*}$ & 0.000 \\
\hline Age x Score Use of Prosthesis & $0.495^{*}$ & 0.000 \\
\hline Age x Score Prosthesis Needed & 0.196 & 0.197 \\
\hline
\end{tabular}

* Statistically significant Spearman correlation coefficient.

Source: The authors.

Oral health surveys provide a safe basis for assessing the current condition of a population and its future oral care needs, as well as the development of prevention programs. WHO has a traditional methodology for epidemiological surveys, which includes a description of diagnostic criteria that can be readily understood and applied by public health programs worldwide ${ }^{15}$. Considering this context, this study followed the standards recommended by WHO in order to realistically portray the oral health conditions of visually impaired people.

A slight male prevalence was observed among visually impaired individuals, corroborating the study by Maciel et al. ${ }^{16}$, in which the number of men was also predominant; however, visual impairment is not more common in males, as evidenced by Malta et.al. ${ }^{1}$, which confirms that there is no difference between men and women among visually impaired people.

In this study in the level of visual impairment there is a slight prevalence of total blindness, and this deficiency was considered acquired throughout life by the majority of those surveyed in this study. The type and level of disability did not influence the study, that is, the difficulties do not depend on total blindness or low vision and whether it is acquired or not. Contrary to the study by Aanise ${ }^{17}$, in which there are greater periodontal changes and deficits in health maintenance, for patients with total visual impairment than those with partial deficiency.

It should also be noted that people with visual impairment usually have the same stomatological pattern as non-disabled patients. However, the prevalence of periodontal disease may be higher because of the difficulty achieving adequate oral hygiene without visual feedback ${ }^{18}$.

According to the American Dental Association (ADA), for the correct maintenance of oral hygiene, the frequency of brushing, the use of toothbrush and toothpaste, and the use of dental floss are essential ${ }^{19}$. This study showed that most of participants brushed their teeth more than twice a day, and used toothbrush and toothpaste most of the time, which is similar to what was observed in other studies ${ }^{20,21-23}$. However, the majority did not use dental floss and mouthwash, which helps maintain oral health. This was also found by Watson et al. ${ }^{20}$ and Cericato and Fernandes ${ }^{24}$. This may be related to the poor motor skills demonstrated by visually impaired people. They have difficulty maintaining proper oral hygiene given the low use of dental floss and mouthwash associated with incorrect brushing methods.

This low frequency of flossing impacts on periodontal disease and the use of prosthesis, that is, the more that flossing the less prosthesis use and the less periodontal disease, this is observed in this study since the values of use of dental floss and denture and CPI scores were statistically significant.

Due of the low frequency of flossing, these individuals have incorrect methods for maintaining oral hygiene, which are due to the lack of oral health education programs directed to those individuals, which can be observed in this study in which the majority of the respondents reported having learned to perform oral hygiene with their parents similar to what was observed in the study by Mudunuri et al. ${ }^{25}$. This does not mean that parents did not teach their children correctly, but this learning should come from qualified professionals, who are responsible for teaching it, which in this case it is the dental surgeon ${ }^{26}$.

The poor motor skills of visually impaired people when attempting to perform satisfactory oral hygiene, in association with incorrect brushing methods, generate an accumulation of biofilm, which can cause periodontal issues; therefore, it is important to evaluate their periodontal condition.

The number of teeth excluded in this study was $33.7 \%$, similarly to that found by Souza Filho et al. ${ }^{27}$, in which the number of excluded teeth was $32.3 \%$, demonstrating a high prevalence of dental loss in an adult age group of approximately 47 years. The increase in age has a positive correlation with the CPI score, that is, with the passage of age, in this study, a greater number of periodontal problems were observed and, consequently, greater tooth loss. This can be confirmed in this study since there is a moderate correlation between CPI score and prosthesis use, this shows that periodontal problems are related to edentulism and oral rehabilitation is essential for the individual's self-esteem.

Therefore, it is important to evaluate the use and need of dental prosthesis, since every individual must be rehabilitated so that their mastication and aesthetic functions are returned. In this study it was evaluated that most of the interviewees do not use any type of prosthesis in the upper and lower arches, and those who use a large part use upper and lower total prosthesis, which corroborates with what was evaluated in SB Brazil $2010^{28}$. This demonstrates a high prevalence of total prosthesis use for a mean age of 47.2 years, that is, this age group had a high number of missing teeth, both in the visually impaired and in the Brazilian population. 
This prevalence is considered high; when comparing to studie ${ }^{29,30}$ on edentulism in the elderly, in which the average age is 70 years old, it was observed that, despite the same used prosthesis more frequently, the most used one was the total prosthesis or a combination of partial and total, which is similar to what was observed in this study.

Dental losses have a large impact on the general health and well-being of individuals. In this study, age and use of prosthesis presented a significant correlation, that is, dental losses tend to occur more frequently over the years, and although they are still culturally considered a part of the natural aging process, these losses should not be ignored. There is evidence that tooth loss leads to a decrease in quality of life, and only prosthetic rehabilitation can reverse this condition $^{31}$. For that reason, it is important to evaluate the need for dental prosthesis in individuals with visual impairment. In addition to the difficulties routinely associated with the lack of inclusion, they need good quality of life; regarding oral health, this is only possible if the individual has his/her chewing and aesthetic functions in harmony ${ }^{32}$.

Thus, in this study, it was observed that more than half of the interviewees needed some kind of prosthesis, among them the most necessary ones were partial in one or two maxillaries, the same can be observed in SB Brazil 201028, in which the majority needed prosthesis and this need was for partial prosthesis in a jaw. Despite the similarity between the two studies, the needs of visually impaired people are somewhat lower, but they require a prosthesis in both jaws, which implies a worse condition in comparison to the general population.

Although the periodontal conditions and edentulism of visually impaired people are similar to those of the general population in some points, the high number of dental losses and the need for prosthesis demonstrated by this study should be highlighted. Oral health education programs targeted at visually impaired people by dental professionals are needed both in dental care and in institutes for blind people, so that these individuals can better maintain oral hygiene and have fewer periodontal problems and dental losses and improve their quality of life $\mathrm{e}^{10,32,33}$.

As limitations of this study the lack of a control group and a small sample stand out. Therefore, further studies are recommended in order to develop public oral health policies and protocols for the visually impaired people, improving the oral health of this population and consequently their quality of life.

\section{Conclusion}

Although people with visual impairments often perform oral hygiene practices, dental hygiene is often out of date due to the lack of flossing. This lag is due to the lack of public policies aimed at this population as well as educational measures of promotion in oral health. This fact reflects directly on the oral health conditions of those patients who did not have these guidelines in the past, according to the study, since these individuals presented teeth with periodontal problems and a high prevalence of edentulism.

\section{References}

1- Malta DC, Stopa SR, Canuto R, Gomes NL, Mendes VLF, Goulart BNG, et al. Self-reported prevalence of disability in Brazil, according to the National Health Survey, 2013. Ciênc Saúde Coletiva 2016;21(10):3253-64. http://dx.doi. org/10.1590/1413-812320152110.17512016

2- Gil M. Visual impairment. Brasília: Ministry of Education; 2000 .

3- Silveira ER, Schardosim LR, Goettems ML, Azevedo MS, Torriani DD. Educação em saúde bucal direcionada aos deficientes visuais. Rev Bras Educ Espec 2015;21(2):289-98. doi: http://dx.doi.org/10.1590/S141365382115000200009.

4- Brasil. Ministério da Saúde. Saúde de A a Z: saúde da pessoa com deficiência. [acesso em 20 jan 2019]. Disponível em http://portalms.saude.gov.br/saude-de-a-z/saude-da-pessoacom-deficiencia.

5- Brasil. Ministério da Saúde. SAGE - Sala de Apoio à Gestão Estratégica. Viver sem limite. CEO Qualificado. [acesso em 20 jan 2019]. Disponível em http://sage.saude.gov.br/\#.

6- Debnath A, Srivastava BK, Shetty P, Eshwar S. New vision for improving the oral health education of visually impaired children: a non randomized control trial. J Clin Diagn Res. 2017;11(7):ZC29-32.

7- Chowdary PB, Uloopi KS, Vinay C, Rao VV, Rayala C. Impact of verbal, braille text, and tactile oral hygiene awareness instructions on oral health status of visually impaired children. J Indian Soc Pedod Prev Dent 2016;34(1):43-7.

8- Sardana D, Goyal A, Gauba K, Kapur A, Manchanda S. Effect of specially designed oral health preventiveprogramme on oral health of visually impaired children: use of audio and tactile aids. Int Dent J 2018. doi: 10.1111/idj.12436.

9- Massoni ACLT, Porto E, Dantas LS, Santos PJO, Silva HP. Training, practices and difficulties of dentists in the care of children and adolescents with special needs in the primary health care. Pesq Bras Odontoped Clin Integr 2017;17(1):e3650. doi: http://dx.doi.org/10.4034/ PBOCI.2017.171.51

10- Yalcinkaya SE, Atalay T. Improvement of oral hygiene knowledge in a group of visually. Oral Health Prev Dent 2006;4(4):243-53.

11- Carranza Junior FA, Newman MG. Periodontia clínica. Rio de Janeiro: Guanabara Koogan; 1997.

12- Moreira RS, Nico LS, Tomita NE. O risco espacial e fatores associados ao edentulismo em idosos em município do Sudeste do Brasil. Cad Saude Publica 2011;27(10):2041-54. doi: http://dx.doi.org/10.1590/S0102-311X2011001000017.

13- Sánchez MTP, Justicia MDL. Autoconcepto de estudiantes universitarios con discapacidad visual, auditiva y motora. Rev Latinoam Psicol 2017;44 (2):87-98.

14- Silva JCGS, da Costa AB, Simioni SMR, Almeida MA, Orlando RM. Do enfrentamento à autoaceitação da deficiência visual. Rev Cient Claret Educ 2017;7(2):43-60.

15- World Health Organization. Oral health surveys: basic methods. Geneva: WHO; 2013. 
16- Maciel MAS, Cordeiro PM, d'Ávila S, Godoy GP, Alves RD, Lins RDAU. Assessing the oral condition of visually impaired individuals attending the Paraíba Institute of the Blind. Rev Odonto Ciênc 2009;24(4):354-60.

17- Aanise JZ. Periodontal disease and oral hygiene in a group of blind and sighted Israeli teenagers 14-17 years of age. Community Dent Oral Epidemiol 1979;(6):353-6.

18- Carvalho ACP, Figueira LCG, Utumi ER, Oliveira CO, Silva LPN, Pedron IG. Considerações no tratamento odontológico e periodontal do paciente deficiente visual. Rev Odontol Bras Central 2010;19(49): 97-100.

19- American Dental Association. Keeping your gums healthy: brushing your teeth J Am Dent Assoc 2015;146(4):A46.

20- Watson EK, Moles DR, Kumar N, Porter SR. The oral health status of adults with a visual impairment, their dental care and oral health information needs. Brit Dent J 2010; 208, E15.

21- Gómez MV, Toledo A, Carvajal P, Gomes SC, Costa RSA, Solanes F, et al. A multicenter study of oral health behavior among adult subjects from three South American cities. Braz Oral Res 2018;32:e22. doi: http://dx.doi.org/10.1590/18073107bor-2018.vol32.0022.

22- Reddy VK, Chaurasia K, Bhambal A, Moon N, Reddy EK. A comparison of oral hygiene status and dental caries experience among institutionalized visually impaired and hearing impaired children of age between 7 and 17 years in central India. J Indian Soc Pedod Prev Dent 2013;31(3):1415. doi: http://dx.doi.org/10.4103/0970-4388.117963.

23- Kovačević V, Milosavljević M, Rančić N, Daković D. Assessment of the periodontal health and community periodontal index in the Army of Serbia. Vojnosanit Pregl 2015;72(11):953-60.

24- Cericato GO, Fernandes APS. Implicações da deficiência visual na capacidade de controle de placa bacteriana e na perda. Rev Fac Odontol UPF 2008;13(2):17-21.
25- Mudunuri S, Sharma A, Subramaniam P. Perception of complete visually impaired children to three different oral health education methods: a preliminary study. J Clin Pediatr Dent 2017;41(4):271-4. doi: http://dx.doi.org/10.17796/10534628-41.4.271.

26- Bordin D, Fadel CB, Moimaz SAS, Garbin CAS, Saliba NA. Considerações de profissionais e usuários sobre o serviço público odontológico: um aporte para o planejamento em saúde. Rev APS 2016;19(2):221-9.

27- Souza Filho MD, Nogueira SDM, Martins MCC. Avaliação da saúde bucal de deficientes visuais em Teresina-PI. Arq Odontol 2010; 45(2):66-74.

28- Brazil. SB Brazil 2010: National Oral Health Survey: main results. Brasília: Ministry of Health; 2012.

29- Agostinho ACMG, Campos ML, Silveira JLGC. Edentulismo, uso de prótese e autopercepção de saúde bucal entre idosos. Rev Odontol UNESP 2015;44(2):74-9. doi: http://dx.doi. org/10.1590/1807-2577.1072.

30- Gerritsen AE, Allen PF, Witter DJ, Bronkhorst EM, Creugers NH. Tooth loss and oral health-related quality of life: a systematic review and meta-analysis. Health Qual Life Outcomes 2010;8:126. doi: http://dx.doi.org/10.1186/14777525-8-126.

31- Vyas S, Nagarajappa S, Dasar PL, Mishra P. Impact of comprehendible learning modes on oral health among visually impaired adults. Spec Care Dentist 2018;38(5):27180. doi: http://dx.doi.org/10.1111/scd.12313.

32- Brandão MCCA, Lemos NR, Rocha JS, Triques CN, Vieira LDS, Amaral LD. Características em saúde bucal de deficientes visuais: revisão de literatura. Rev Odontol Planal Cent 2016;6(1):18-21.

33- Castro CO, Oliveira KS, Carvalho RB, Garbin CAS, Santos KT. Programas de educação e prevenção em saúde bucal nas escolas: análise crítica de publicações nacionais. Odontol Clín-Cient 2012;11(1):51-6. 